\title{
Elimination of nasal obstruction improves pulmonary functions and oxygenation
}

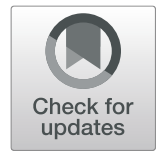

Eman Sobh $^{1^{*}}$ (D), Fatma Elhussieny ${ }^{2}$ and Taghreed Ismail ${ }^{3}$

\begin{abstract}
Background: Nasal obstruction is a significant medical problem. This study aimed to examine the effect of nasal obstruction and nasal packing on arterial blood gases and pulmonary function indices, and the impact of the elimination of nasal obstruction on preoperative values.

Results: The mean age of the study population was $26.6 \pm 10.1$ years, males represented $50.8 \%$. Spirometric indices showed statistically significant improvement (preoperative forced expiratory volume in 1st second $66.9 \pm 13.9$ vs $79.6 \pm 14.9$ postoperative and preoperative forced vital capacity $65.5 \pm 12.7$ vs $80.4 \pm 13.8$ postoperative). Oxygen saturation was significantly lower during nasal packing ( $95.6 \pm 1.6$ preoperative vs $94.7 \pm 2.8$ with nasal pack), and significant improvement $(97.2 \pm 1.4)$ was observed after removal of the nasal pack. Nasal obstruction scores significantly improved.

Conclusion: The results of this study indicate that either simple nasal obstruction or nasal packing may cause hypoxemia and abnormalities in lung function tests. Hypoxemia was more evident with nasal packing.

Keywords: Nasal obstruction, Nasal packing, Pulmonary function tests, Spirometry, Hypoxemia, Arterial blood gases, Respiratory function, Airway obstruction, Oxygen saturation
\end{abstract}

\section{Background}

Nasal airway obstruction and nasal congestion are significant presentations in otorhinolaryngology practice. They carry significant discomfort, economic impact, and negative effect on the quality of life $[1,2]$. The nose is the primary route of breathing in humans and it carries significant functions including humidification, warming, and filtration of inspired air [3]. In normal conditions, the nasal airway accounts for $\geq$ $50 \%$ of total airway resistance, with most of this contribution arising from the anterior part of the nose [4], this resistance is increased in pathologic conditions [5]. Nasal resistance is different from side to side and because of nasal mucosal changes in nasal turbinate in a cycle pattern (nasal cycle) [6]. This cycle occurs in about $80 \%$ of the adult population and this cycle plays a role in respiratory defense [7]. Changes in respiratory mechanics and arterial blood gases may occur

\footnotetext{
* Correspondence: emansobh2012@Gmail.com; emansobh@azhar.edu.eg

${ }^{1}$ Chest Diseases Department, Faculty of Medicine for Girls, Al-Azhar

University, 11517 Al-Abbassia, Cairo, Egypt

Full list of author information is available at the end of the article
}

due to oral breathing secondary to nasal obstruction [8]. In patients with permanent unilateral nasal obstruction, the nasal cycle can contribute to a significant increase in the total resistance of the airways [7]. Previous studies reported that simple nasal obstruction was associated with hypoxemia [9] and changes in respiratory function tests [10]. Nasal packing is a common practice after nasal operations. Some studies reported that nasal packing following nasal surgeries may result in hypoxemia and/or hypercapnia [11]. Other studies reported that nasal packing with airway tubes did not result in postoperative respiratory dysfunction or hypoxemia [12]. Surgical correction of nasal obstruction is a common rhinolaryngology practice; this correction may improve physiologic changes in pulmonary function and on arterial blood gases associated with nasal obstruction. This study aimed to examine the effect of nasal obstruction and nasal packing on arterial blood gases and pulmonary function indices and the impact of the elimination of nasal obstruction on preoperative values. 


\section{Methods}

\section{Study design and population}

In this time series hospital-based study, we enrolled consecutive 59 patients with nasal obstruction who are eligible for corrective surgery as recommended by their management team. The study team has no role in patient selection or operative decisions.

\section{Data collection}

Detailed history was taken. Clinical examination was performed by otorhinolaryngologist; examination of the external nose and anterior rhinoscopy, and diagnostic nasal endoscope for the examination of the nasal cavity to detect the cause of nasal obstruction (polyp, septal deviation, or tumor). Respiratory assessment by pulmonologist was also performed, and patients who have evidence of chronic respiratory disease, chronic heart disease, and neuromuscular disease were excluded from the study. Age, sex, symptoms, and smoking history were recorded. Nasal obstruction symptom evaluation (NOSE) score [13] was used to assess the degree of nasal obstruction pre and postoperative. The score is formed of five items and each item represents symptom (nasal stuffiness, nasal obstruction, trouble breathing, trouble sleeping, unable to get enough air during exercise); each patient takes a score from 0 to 4 ( 0 represent not a problem and 4 represent a severe problem); the maximum result is 20 which will be multiplied by 5 to get a score from 100 .

1. Routine pre-operative investigations were recorded including laboratory investigations and radiologic studies (computed tomography scan of the nose and paranasal sinus to determine the cause of nasal obstruction and plain chest radiography).

2. Arterial blood gases (RAPID lab blood gas analyzer Siemens) were done at three-time points for each patient: 1st sample at baseline (before surgery), 2nd sample on the 2nd postoperative day just before removal of nasal packing, while the 3rd sample was obtained 1 week postoperative after removal of the nasal pack.

3. Spirometry was performed and interpreted by an experienced pulmonologist according to ERS/ATS guidelines [14] using "Spirosift SP-5000 FUKUDA Denshi, Japan" spirometer. The procedure was done at two-time points: 1 st measurement at baseline (pre-operative) and the 2nd measurement was done 1 week postoperative after removal of the nasal pack. The patient was asked to breathe normally several times then taking a deep breath and exhale as deep and as fast as he/she can. We recorded forced vital capacity (FVC), forced expiratory volume in the first second (FEV1), and FEV1/FVC.
This procedure is repeated three times and the best technically acceptable reading is recorded. Spirometry could not be done at the $48 \mathrm{~h}$ postoperative time point as the forced expiration required during test performance may increase the risk of bleeding or displacement of nasal packing.

4. Septoplasty was performed using the functional endoscopic sinus surgery (FESS) technique under general anesthesia and followed by a bilateral nasal packing using Tampon nasal packs.

5. Removal of the nasal pack was done $48 \mathrm{~h}$ postoperative day and the patient was examined by the otorhinolaryngologist.

\section{Data management}

All data were recorded anonymously and fed to excel, coded, and revised. Statistical analysis was performed using SPSS software for Windows (Version 20.0; SSPS Inc., Chicago, IL). Numerical data were presented as mean \pm SD whereas categorical data were presented as number and percentage. The paired sample $t$ test was used to compare numerical with normal distribution. Mann-Whitney test was used for non-parametric comparisons. The general linear model was used for the comparison of repeated measures. Multiple linear logistic regression model was done to determine factors affecting hypoxia. The level of significance was considered as $p<0.05$ for all tests.

\section{Results}

Fifty-nine patients were operated on for correction of the cause of nasal obstruction between March 2018 and February 2019. Their mean age was $26.6 \pm 10.1$ years, males represented $50.8 \%$ of cases, $13.6 \%$ were current smokers. Nasal obstruction, rhinorrhea, postnasal discharge, and headache were the most prevalent symptoms (Tables 1 and 2). No significant statistical difference between male and female in age, BMI, duration of nasal obstruction, and baseline nasal obstruction score $(\mathrm{p}=0.837,0.187,0.801$, 0.717 , respectively). Preoperative $\mathrm{PaO} 2$ was significantly higher in women than in men $(\mathrm{p}=0.01)$.

Spirometric indices were impaired at baselines and showed significant improvement postoperatively (Table 3). No statistical significant difference in pulmonary functions between males and females either at baseline or postoperatively. Hypoxemia was observed in some cases pre-operatively, and there was a significant decrease in partial pressure of oxygen $\left(\mathrm{PaO}_{2}\right), \mathrm{pH}$, and oxygen saturation $\left(\mathrm{SPO}_{2} \%\right)$ with nasal packing. Oxygenation significantly improved postoperatively after removal of the pack (Table 4, Figs. 1 and 2).

FVC forced vital capacity, FEV1 forced expiratory volume in first second of forced vital capacity maneuver, NOSE nasal obstruction symptom evaluation 
Table 1 Demographic data of the studied group

\begin{tabular}{ll}
\hline Character & Values \\
\hline Age: (years) mean \pm SD (range) & $26.6 \pm 10.1(18.0-56.0)$ \\
Sex: & \\
$\quad$ Male & $30(50.8 \%)$ \\
$\quad$ Female & $29(49.2 \%)$ \\
BMI mean \pm SD (range) & $26.6 \pm 4.6(18.5-40.6)$ \\
- Normal & $20(33.9 \%)$ \\
- Overweight & $29(49.2 \%)$ \\
- Obese & $10(16.9 \%)$ \\
Smoking & \\
- Smokers & $8(13.6 \%)$ \\
- Non-smoker & $51(86.4 \%)$ \\
Pack/year $(\mathbf{n}=\mathbf{8})$ & $13.8 \pm 5.2$ \\
\hline
\end{tabular}

$\mathrm{PaO} 2$ partial pressure of oxygen, $\mathrm{PaCO} 2$ partial pressure of carbon dioxide, SPO2 oxygen saturation

Factors significantly affecting postoperative $\mathrm{SPO}_{2 \%}$ were preoperative nasal obstruction score, RBCs number, and sex (higher SPO2 was higher when preoperative obstruction score is low, a higher number of RBCs and being a female) (Table 5).

NOSE nasal obstruction symptom evaluation

Table 2 Clinical data of the studied group

\begin{tabular}{ll}
\hline Character & Value \\
\hline Nasal obstruction & $59(100 \%)$ \\
Rhinorrhea & $51(86.4 \%)$ \\
Headache & $49(83.1 \%)$ \\
Postnasal discharge & $48(81.4 \%)$ \\
Sneezing & $31(52.5 \%)$ \\
Itching & $29(49.2 \%)$ \\
Snoring & $23(39 \%)$ \\
Epistaxis & $23(39 \%)$ \\
Dyspnea & $23(39 \%)$ \\
Temporal discomfort & $15(25.4 \%)$ \\
Smell disorders & $13(22 \%)$ \\
Cough & $13(22 \%)$ \\
Nocturnal apnea & $3(5.1 \%)$ \\
Operative indication & \\
- Nasal polyposis & $47(79.7 \%)$ \\
- Deviated nasal septum & $12(20.3 \%)$ \\
RBCs & $5.0 \pm 0.4(4.3-6)$ \\
Platelet count & $269.9 \pm 50.5(160-388)$ \\
Comorbidities & \\
HCV positive & $2(3.4 \%)$ \\
Duration of nasal obstruction (years) & Median 5 (2-12) \\
\hline
\end{tabular}

\section{Discussion}

The results of this study revealed that patients with nasal obstruction had impaired pulmonary function tests (decreased FVC, FEV1) which are significantly improved postoperative (Table 3). Previous studies $[15,16]$ reported lower FEV1, FVC in patients with the nasal obstruction which improved following surgery. However; Yiğit et al. [12] reported a small non-significant reduction in the values of FEV1, FVC in patients with nasal packing. This could be attributed to the fact that they used airway tubes for packing which prevented total nasal obstruction.

Various studies $[10,17,18]$ reported lower pulmonary functions in patients with chronic rhinosinusitis resistant to medical treatment. These changes may be symptomatic or asymptomatic. Yousof et al. [10] reported significantly lower values of mean FVC, FVC\%, FEV1, and FEV1\% in the group of patients with chronic medically resistant rhinosinusitis compared with the control healthy group which improved following surgery.

In our study, all patients had symptoms of nasal obstruction and most of them had nasal polyposis (79.7\%). The effect of nasal obstruction on spirometry can be explained by the nasal-lung systemic cross-talk in which airway inflammation whatever the site is reflected on all airways either upper or lower and the presentation depends on the severity and contributing factors [19].

In our study, patients with nasal obstruction had mild hypoxemia and decreased oxygen saturation. Oxygenation was significantly impaired further with nasal packing $(\mathrm{PaO} 2$ slightly decreased while oxygen saturation is significantly decreased during packing). All these changes are improved 1 week postoperative following removal of the nasal pack. On the other hand, no significant changes were observed in carbon dioxide level (Table 4, Figs. 1 and 2).

The same results were reported in previous studies [16, 20-22]. Cassisi et al. [21] reported that nasal packing caused a significant decrease in $\mathrm{PaO}_{2}$, but it had little effect on $\mathrm{PaCO}_{2}$, and that low $\mathrm{PO}_{2}$ returned to normal after the pack had been removed. Ogretmenoglu et al. [20] showed that nasal packing caused a significant decrease in $\mathrm{O}_{2}$ saturation, a borderline decrease in PO2, insignificant changes in $\mathrm{PCO}_{2}$. Saxena et al. [22] demonstrated a significant increase in partial arterial oxygen saturation percentages, as well as peak and forced expiratory flow speed in a group of patients with deviated nasal septum 1 month after the surgical correction. Mandour et al. [16] reported statistically significant improvement in nocturnal oxygen in patients with nasal obstruction after surgery.

On the other hand, Taasan et al. [23] study failed to report significant changes in nocturnal oxygen saturation in healthy subjects with total nasal packing. However, a 
Table 3 Pulmonary functions and nasal obstruction score pre and postoperative

\begin{tabular}{|c|c|c|c|c|c|c|}
\hline & Score (mean = & & $95 \% \mathrm{Cl}$ & ence & Paired & $P$ value \\
\hline & Preoperative & Postoperative & Lower & Upper & $\begin{array}{l}\text { sample } \\
\text { t test }\end{array}$ & \\
\hline FVC \% & $65.5 \pm 12.7$ & $80.4 \pm 13.8$ & -18.0 & -11.7 & -9.5 & $<0.0001$ \\
\hline FEV1 \% & $66.9 \pm 13.9$ & $79.6 \pm 14.9$ & -15.9 & -9.5 & -8.0 & $<0.0001$ \\
\hline FEV1/ FVC \% & $88.0 \pm 9.7$ & $87.6 \pm 8.2$ & -1.8 & 2.6 & 0.4 & 0.7 \\
\hline NOSE score & $63.2 \pm 10.9$ & $27.0 \pm 6.1$ & 34.1 & 38.3 & 34.0 & $<0.0001$ \\
\hline
\end{tabular}

very small sample number (only seven patients) was included. Yigit et al. [12] conducted a study on 40 patients: 20 with nasal packing with airway tubes and 20 with nasal packing without airway tubes. Their results showed decreased $\mathrm{PO} 2$ and increased $\mathrm{PCO} 2$ in patients with nasal packing without airway tubes postoperatively. They explained these results by the hypoxia following a nasal obstruction.

The results of the current study and previous studies refer to a negative effect of nasal obstruction either pathologic or artificial by nasal packing on arterial oxygen status. This may be explained by the following: the obstructed air passage by pathologic condition and the same effect provided by the nasal packing may result in secondary hypoventilation and an increase in bronchomotor tone and activation of naso-pulmonary reflex which leads to decreased pulmonary compliance and increased pulmonary and airway resistance [21, 22]. The increased bronchomotor tone led to increased turbulence, which altered the distribution of alveolar ventilation, leading to hypoxemia [21]. Besides, mechanical obstruction of the nose may activate trigeminal receptors in nasal mucosa resulting in naso-pulmonary reflex. The pressure of nasal packs may provide additional stimulation to these receptors [22]. Nasal packing causes complete nasal obstruction leading to oral breathing and may contribute to the development of sleep-disordered breathing which leads to a further decrease in oxygen saturation $[24,25]$. Other causes of venous admixture (e.g., pneumonia or right-to-left shunting) were ruled out based on an unremarkable medical history and physical examination, and radiology.

Oral breathing in cases of nasal obstruction may be a contributing factor as oral breathing reduces the activation of nasal receptors, with the deactivation of the nasal respiratory reflex and reduction of spontaneous ventilation [26].

The exact mechanism of improvement after surgery is unknown and it may be attributed to the correction of previous factors.

Our results showed that female sex, high RBCs number, and low preoperative nasal obstruction score were associated with high postoperative SPO2. This may be attributed to physiologic mechanisms as RBCs are carriers for oxygen; in those with low NOSE score, the mechanical and pathophysiologic mechanisms causing impaired oxygenation are less activated. Besides, women had significantly higher $\mathrm{PaO} 2$ at baseline.

Table 4 Pre-operative with nasal pack and postoperative blood gases values

\begin{tabular}{|c|c|c|c|c|c|c|c|}
\hline & \multicolumn{3}{|c|}{ Score (mean \pm SD) } & \multicolumn{2}{|l|}{$95 \% \mathrm{Cl}$} & \multirow{2}{*}{$\begin{array}{l}\text { Paired } \\
\text { sample } \\
\text { t test }\end{array}$} & \multirow[t]{2}{*}{$P$ value } \\
\hline & Preoperative & With nasal packing & Postoperative & Lower & Upper & & \\
\hline $\mathrm{pH}$ & $7.4 \pm 0.03$ & $7.4 \pm 0.05$ & $7.4 \pm 0.03$ & $\begin{array}{l}*^{*}-6.4 \\
*^{*}-6.4 \\
* * *-.002\end{array}$ & $\begin{array}{l}-6.3 \\
-6.3 \\
0.02\end{array}$ & 8.6 & $\begin{array}{l}<0.0001 \\
<0.0001 \\
0.1\end{array}$ \\
\hline PAO2 (mmHg) & $86.1 \pm 11.2$ & $83.5 \pm 13.4$ & $93.7 \pm 13.1$ & $\begin{array}{l}*-1.2 \\
* *-12.0 \\
* * *-15.1\end{array}$ & $\begin{array}{l}6.3 \\
-3.3 \\
-5.3\end{array}$ & 12.0 & $\begin{array}{l}0.2 \\
0.001 \\
<0.0001\end{array}$ \\
\hline $\mathrm{PaCO} 2(\mathrm{mmHg})$ & $39.9 \pm 9.7$ & $39.4 \pm 10.2$ & $38.6 \pm 8.7$ & $\begin{array}{l}*-2.4 \\
*^{*}-2.0 \\
*^{* *}-2.8\end{array}$ & $\begin{array}{l}3.3 \\
4.6 \\
4.4\end{array}$ & 0.3 & $\begin{array}{l}0.7 \\
0.4 \\
0.7\end{array}$ \\
\hline $\mathrm{HCO} 3$ & $22.8 \pm 1.8$ & $23.4 \pm 2.3$ & $22.9 \pm 1.9$ & & & 1.9 & 0.2 \\
\hline SPO2\% & $95.6 \pm 1.6$ & $94.7 \pm 2.8$ & $97.2 \pm 1.4$ & $\begin{array}{l}* 0.3 \\
* *-3.1 \\
* * *-1.9\end{array}$ & $\begin{array}{l}1.6 \\
-1.7 \\
-1.1\end{array}$ & 50.5 & $\begin{array}{l}0.004 \\
<0.0001 \\
<0.0001\end{array}$ \\
\hline
\end{tabular}

*Preoperative versus packing

**Packing versus postoperative

***Preoperative versus postoperative 


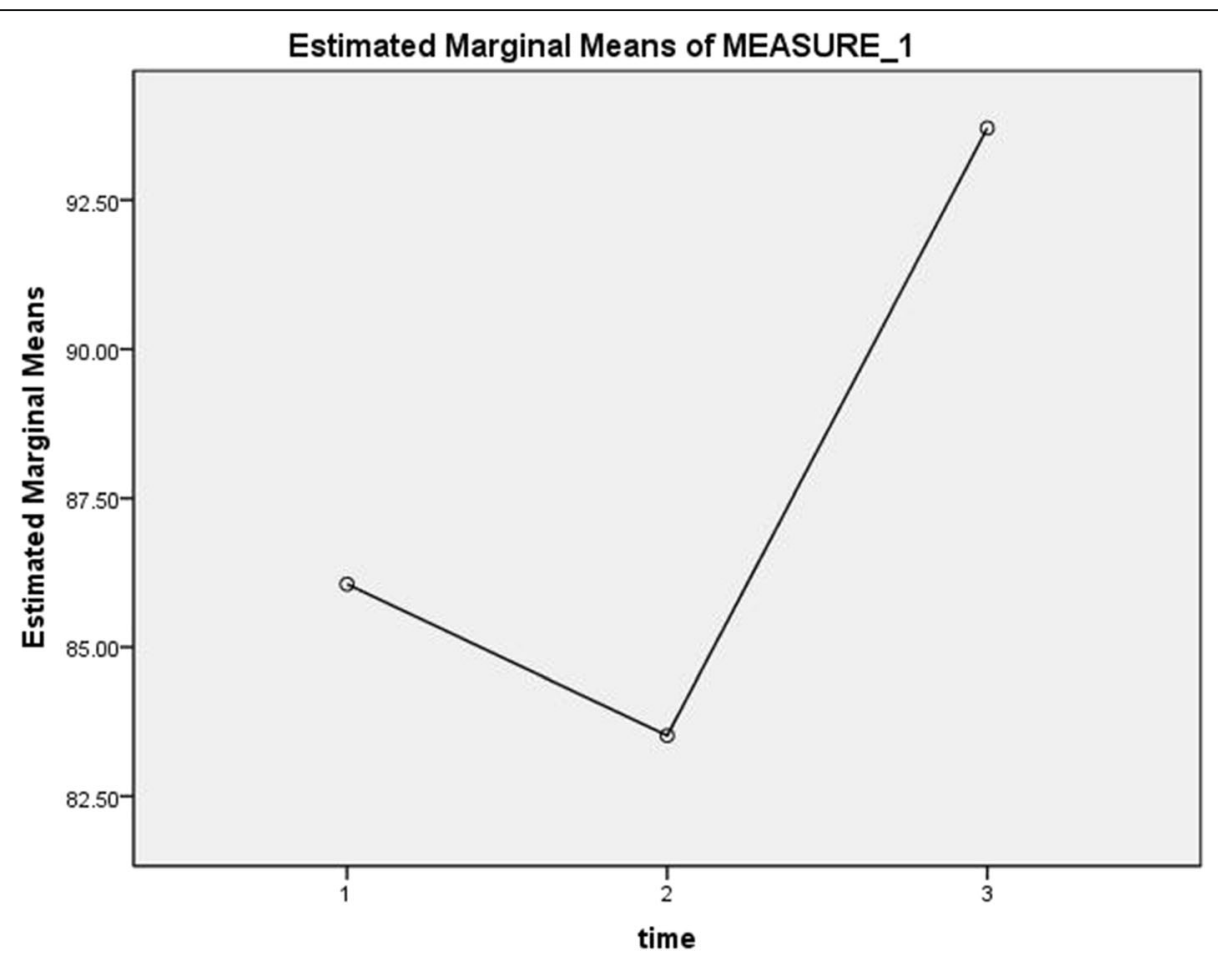

Fig. 1 Changes observed in $\mathrm{PaO}_{2}$ over time. Hypoxemia was present at baseline and a further decrease was observed with nasal packing and significant improvement was detected after removal of nasal packs

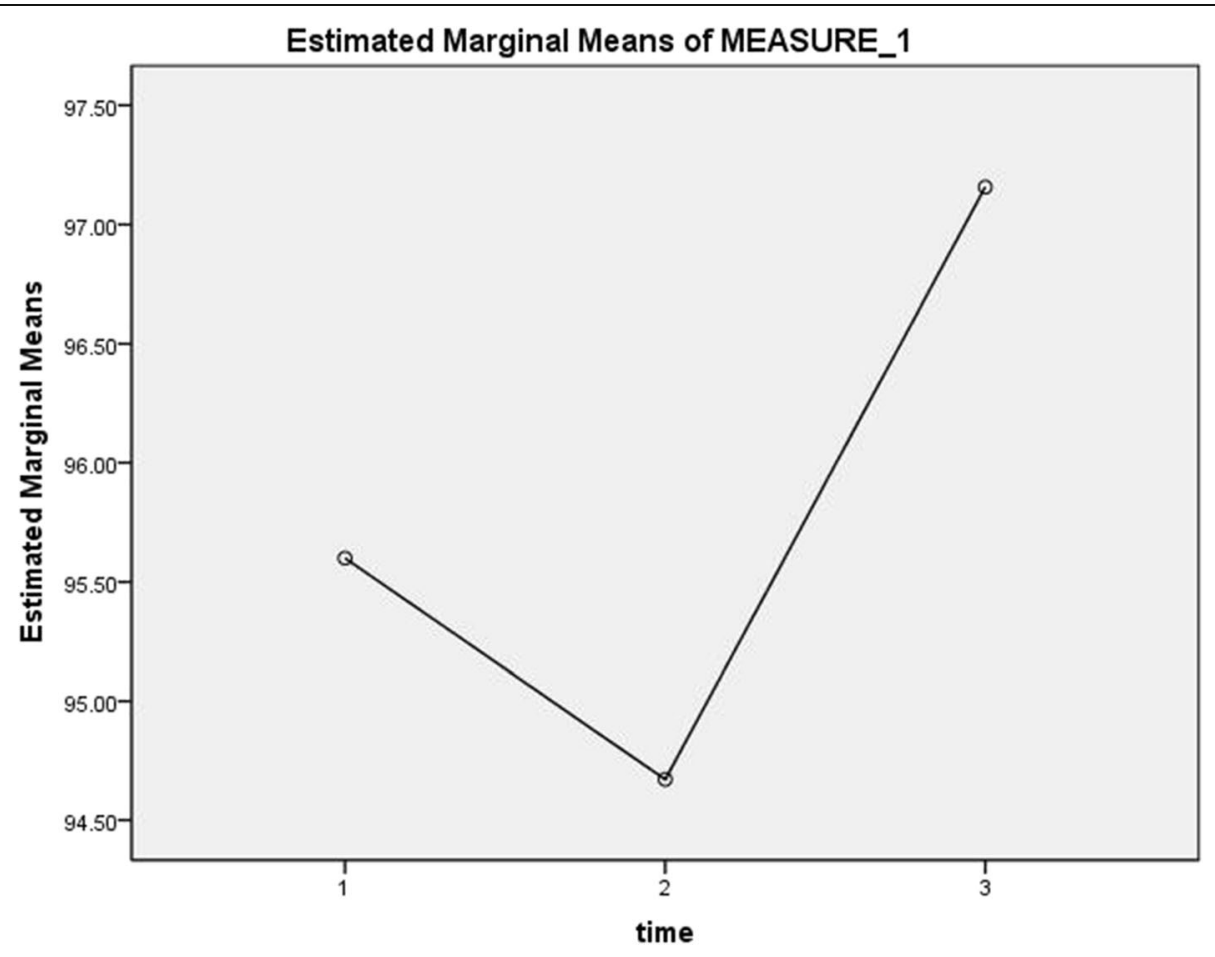

Fig. 2 Changes observed in oxygen saturation over time. Oxygen saturation was low at baseline and a further decrease was observed with nasal packing and significant improvement was detected after removal of nasal packs 
Table 5 Multiple linear regression model of factors affecting SPO2

\begin{tabular}{|c|c|c|c|c|c|c|c|}
\hline \multirow[t]{2}{*}{ Model } & \multicolumn{2}{|c|}{ Unstandardized coefficients } & \multirow{2}{*}{$\begin{array}{l}\text { Standardized coefficients } \\
\text { Beta }\end{array}$} & \multirow[t]{2}{*}{$\mathbf{T}$} & \multirow[t]{2}{*}{ Sig. } & \multicolumn{2}{|c|}{$95.0 \%$ confidence interval for $B$} \\
\hline & $\bar{B}$ & Std. error & & & & Lower & Upper \\
\hline (Constant) & 92.452 & 2.170 & & 42.598 & $<0.001$ & 88.102 & 96.801 \\
\hline Preoperative NOSE score & -0.066 & 0.014 & -0.513 & -4.881 & $<0.001$ & -0.093 & -0.039 \\
\hline $\mathrm{RBC}$ & 1.473 & 0.392 & 00.414 & 3.760 & $<0.001$ & 0.688 & 2.258 \\
\hline sex & 1.012 & 0.300 & 0.365 & 3.371 & 0.001 & 0.410 & 1.614 \\
\hline
\end{tabular}

${ }^{\mathrm{a}}$ Dependent variable: postSPO

\section{Conclusions}

This study finds that nasal obstruction caused lower airway obstruction. At the same time, nasal obstruction either pathologic or artificial impairs oxygenation. Surgical treatment for cases with chronic nasal obstruction may significantly improve pulmonary effects secondary to nasal obstruction. Further studies are required to determine the exact mechanism behind these effects.

\section{Abbreviations}

FVC: Forced vital capacity; FEV1: Forced expiratory volume in the first second of forced vital capacity maneuver; L: Liter; PaO2: Partial pressure of oxygen; PaCO2: Partial pressure of carbon dioxide; SPO2: Oxygen saturation; NOSE: Nasal obstruction symptom evaluation

\section{Acknowledgements}

Not applicable

\section{Authors' contributions}

E.S., F.E., and T. I. contributed to research conception and design, literature review, and revised the work. E.S. drafted the manuscript. F.E. and E.S. contributed to the data collection. T.S. performed the statistical analysis of the data. All authors contributed to writing and critical analysis of the work and revised the manuscript. All authors have read and approved the manuscript.

\section{Funding}

This research did not receive any specific grant from funding agencies in the public, commercial, or not-for-profit sectors.

\section{Availability of data and materials}

The datasets used and/or analyzed during the current study are available from the corresponding author on reasonable request.

\section{Declarations}

\section{Ethics approval and consent to participate}

The study protocol was approved by the ethics committee of our institute (approval number 201908128) and written informed consent was obtained from each participant before enrolment in the study, and all participants had the right to withdraw from the study at any point without giving reason and without any disadvantages of their management.

\section{Consent for publication}

Not applicable

\section{Competing interests}

The authors declare that they have no competing interests.

\section{Author details}

${ }^{1}$ Chest Diseases Department, Faculty of Medicine for Girls, Al-Azhar University, 11517 Al-Abbassia, Cairo, Egypt. ²Ear, Nose and Throat Department, Faculty of Medicine for Girls, Al-Azhar University, Cairo, Egypt. ${ }^{3}$ Public health and Community Medicine Department, Faculty of Medicine, Assiut University, Assuit, Egypt.
Received: 26 March 2021 Accepted: 7 June 2021

Published online: 22 June 2021

\section{References}

1. Stewart M, Ferguson BJ, Fromer L. Epidemiology and burden of nasal congestion. Int J Gen Med. 2010;3:37.

2. Chandra RK, Patadia MO, Raviv J. Diagnosis of nasal airway obstruction. Vol. 42, Otolaryngologic Clinics of North America. Elsevier; 2009. p. 207-25.

3. Geurkink N (1983) Nasal anatomy, physiology, and function. J Allergy Clin Immunol 72(2):123-128. https://doi.org/10.1016/0091-6749(83)90518-3

4. Ferris BG, Mead J, Opie LH. PARTITIONING OF RESPIRATORY FLOW RESISTAN CE IN MAN. J Appl Physiol [Internet]. 19641 [cited 2021 Jan 30];19:653-8. Available from: https://journals.physiology.org/doi/abs/10.1152/jappl.1964.1 9.4.653

5. Hasegawa M, Kern EB. The human nasal cycle. Mayo Clin Proc [Internet]. 19771 [cited 2021 Jan 30];52(1):28-34. Available from: https://europepmc. org/article/med/609283

6. Eccles R. A role for the nasal cycle in respiratory defence. Eur Respir J. 1996;9(2).

7. Passàli D, Tatti P, Toraldo M, De Benedetto M, Peverini F, Caruso G, Marzetti A, Passàli FM, Bellussi LJ. OSAS and metabolic diseases: Round Table, 99th SIO National Congress, Bari 2012. Acta Otorhinolaryngol Ital. 2014;34(3):158.

8. Fitzpatrick MF, McLean H, Urton AM, Tan A, O'Donnell D, Driver HS. Effect of nasal or oral breathing route on upper airway resistance during sleep. Eur Respir J [Internet]. 20031 [cited 2021 Jan 30];22(5):827-32. Available from: https://erj.ersjournals.com/content/22/5/827.

9. Bista M. Effects of bilateral nasal packing on oxygen saturation and blood pressure. J Nepal Med Assoc [Internet]. 2017 [cited 2021 Jan 30];56(208): 442-6. Available from: https://pubmed.ncbi.nlm.nih.gov/29453477/

10. Yousof A, Awada O, Abdel Fattah M, Ahmada S. Pulmonary function tests in patients with chronic rhinosinusitis and the effect of surgery. Egypt J Bronchol [Internet]. 2017 [cited 2021 Jan 30];11(3):283. Available from: https://link.springer.com/articles/10.4103/ejb.ejb_91_16

11. Gupta M, Singh S, Chauhari B (2011) Comparative study of complete nasal packing with and without airways. B-ENT. 7(2):91-96

12. Yigit O, Cinar U, Uslu B, Akgül G, Topuz E, Dadaş B. The effect of nasal packing with or without an airway on arterial blood gases during sleep. Kulak Burun Bogaz Ihtis Derg [Internet]. 2002 [cited 2021 Jan 30];9(5):34750. Available from: https://pubmed.ncbi.nlm.nih.gov/12471281/

13. Stewart MG, Witsell DL, Smith TL, Weaver EM, Yueh B, Hannley MT. Development and Validation of the Nasal Obstruction Symptom Evaluation (NOSE) Scale. Otolaryngol Neck Surg [Internet]. 2004 [cited 2021 Jan 30]; 130(2):157-63. Available from: http://journals.sagepub.com/doi/10.1016/j. otohns.2003.09.016

14. Miller MR, Hankinson J, Brusasco V, Burgos F, Casaburi R, Coates A, et al. Standardisation of spirometry [Internet]. Vol. 26, European Respiratory Journal. European Respiratory Society; 2005 [cited 2020 Sep 19]. p. 319-38. Available from: https://erj.ersjournals.com/content/26/2/319

15. Panicker VB, Belaldavar BP. Effectiveness of septoplasty on pulmonary function tests in symptomatic deviated nasal septum cases: a prospective study. Int J Otorhinolaryngol Head Neck Surg [Internet]. 201826 [cited 2021 Jan 30];4(3):800. Available from: http://www.ijorl.com

16. Mandour YMH, Abo Youssef SM, Moussa HH (2019) Polysomnographic and pulmonary function changes in patients with sleep problems after septoplasty with turbinectomy. Am J Otolaryngol Head Neck Med Surg. 40(2):187-190

17. Matsumoto K (2015) Chronic rhinosinusitis is associated with airflow obstruction in Japanese never-smokers without asthma. Int J Respir Pulm Med. 30:2(3) 
18. Lee SY, Yoon SH, Song WJ, Lee SH, Kang HR, Kim SS, Cho SH. Influence of chronic sinusitis and nasal polyp on the lower airway of subjects without lower airway diseases. Allergy Asthma Immunol Res. 2014;6(4):310.

19. Togias A. Systemic cross-talk between the lung and the nose. Vol. 164, American Journal of Respiratory and Critical Care Medicine. American Lung Association; 2001. p. 726-7.

20. Ögretmenoglu O, Yllmaz T, Rahimi K, Aksöyek S. The effect on arterial blood gases and heart rate of bilateral nasal packing. Eur Arch Oto-RhinoLaryngology [Internet]. 20024 [cited 2021 Jan 30];259(2):63-6. Available from: https://link.springer.com/article/10.1007/s00405-001-0422-1

21. Cassisi NJ, Biller HF, Ogura JH. Changes in arterial oxygen tension and pulmonary mechanics with the use of posterior packing in epistaxis: a preliminary report. Laryngoscope [Internet]. 19711 [cited 2021 Jan 30];81 (8): 1261-6. Available from: http://doi.wiley.com/10.1288/00005537-19710800000009

22. Saxena A, Srivastava A, Mohan C, Kumar A. Effect of chronic nasal obstruction on pulmonary function. [cited 2021 Jan 30]; Available from: www.jicmr.com

23. Taasan V, Wynne JW, Cassisi N, Block AJ. The effect of nasal packing on sleep-disordered breathing and nocturnal oxygen desaturation. Laryngoscope [Internet]. 19811 [cited 2021 Jan 30];91(7):1163???1172. Available from: http://doi.wiley.com/https://doi.org/10.1288/00005537-1981 07000-00015

24. McNicholas WT. The nose and OSA: variable nasal obstruction may be more important in pathophysiology than fixed obstruction. Eur Respir J [Internet]. 20081 [cited 2021 Jan 30];32(1):3-8. Available from: https://erj.ersjournals. com/content/32/1/3

25. Sedwick JD, Lopez AB, Gajewski BJ, Simons RL. Caudal septoplasty for treatment of septal deviation: aesthetic and functional correction of the nasal base [Internet]. Vol. 7, Archives of Facial Plastic Surgery. Mary Ann Liebert, Inc., publishers 140 Huguenot Street, 3rd Floor New Rochelle, NY 10801 USA; 2005 [cited 2021 Jan 30]. p. 158-62. Available from: https:// www.liebertpub.com/doi/10.1001/archfaci.7.3.158

26. Passali D, Corallo G, Petti A, Longini M, Passali FM, Buonocore G, et al. Studio comparativo sul ruolo dello stress ossidativo nei pazienti con insufficienza respiratoria nasale e sindrome delle apnee ostruttive notturne. Acta Otorhinolaryngol Ital [Internet]. 2016 Dec 1 [cited 2021 Jan 30];36(6): 490-5. Available from: /pmc/articles/PMC5317128/?report=abstract

\section{Publisher's Note}

Springer Nature remains neutral with regard to jurisdictional claims in published maps and institutional affiliations.

\section{Submit your manuscript to a SpringerOpen ${ }^{\circ}$ journal and benefit from:}

- Convenient online submission

- Rigorous peer review

- Open access: articles freely available online

High visibility within the field

- Retaining the copyright to your article

Submit your next manuscript at $\boldsymbol{\nabla}$ springeropen.com 